The University of San Francisco

USF Scholarship: a digital repository @ Gleeson Library |

Geschke Center

Media Studies

College of Arts and Sciences

$10-15-2014$

\title{
Understanding Fair Labor Practices in a Networked Age
}

Tamara Kneese

University of San Francisco, tkneese@usfca.edu

Follow this and additional works at: https://repository.usfca.edu/ms

Part of the Communication Technology and New Media Commons, and the Work, Economy and Organizations Commons

\section{Recommended Citation}

Kneese, Tamara, "Understanding Fair Labor Practices in a Networked Age" (2014). Media Studies. 28.

https://repository.usfca.edu/ms/28

This Article is brought to you for free and open access by the College of Arts and Sciences at USF Scholarship: a digital repository @ Gleeson Library | Geschke Center. It has been accepted for inclusion in Media Studies by an authorized administrator of USF Scholarship: a digital repository @ Gleeson Library | Geschke Center. For more information, please contact repository@usfca.edu. 


\section{Data\&Society}

\section{Understanding Fair Labor Practices in a Networked Age}

by Tamara Kneese, Alex Rosenblat, and danah boyd

Data \& Society Working Paper, October 8, 2014

Prepared for: Future of Work Project supported by Open Society Foundations

\section{Brief Description}

Internet-enabled technologies allow people to connect in unprecedented ways. Although everyday social practices are widespread and well known, these same tools are reconfiguring key aspects of work. Crowdsourcing and distributed labor technologies increasingly allow companies to outsource everything from mundane tasks (e.g., Amazon Mechanical Turk) to professional services (e.g., oDesk). Sharing economy - or peer economy - tools (e.g., Airbnb) allow people to barter goods or services or get paid for these exchanges outside of the dominant business framework. These services have enabled new forms of contract or freelance labor and reduced risk for companies; however, there is often an increase in risk for the associated laborers. At the same time, divisions between what constitutes work, hobby, and volunteerism get blurred, especially as many organizations rely on volunteer labor under the assumption that it's mutually beneficial (e.g., blogs and journalistic enterprises that republish work or see the offer of a platform as valuable in and of itself). While all of these labor issues have unmediated precedents (e.g., free internships), technology magnifies the scale of these practices, minimizes the transactional friction, and increases the visibility of unpaid and freelance work. Collectively, this raises critical questions about what fair labor looks like in a networked world, where boundaries dissolve and existing mechanisms of labor protection do not address the varied work scenarios now available.

\section{US Labor Rights and Protections}

In late $19^{\text {th }}$ and early $20^{\text {th }}$ century America, the labor movement gained traction as urbanization and industrialization propelled workers from farms and into factories. Industrial workers generally lacked protections against mistreatment, overwork, or child labor abuses, and often both worked and lived in deplorable conditions. Early unions like the National Trades' Union, formed in 1834, and Knights of Labor, established in 1869 , were widely popular but their poor organizational structures prevented them from serving as substantial antidotes to unfair labor practices (AFL-CIO, 1981). In 1881, the Federation of Organized Trades and Labor Unions was formed, but was unable to collect dues or enact real change. In 1886, however, the American Federation of Labor formed, and the labor movement was able to take a great leap forward.

Even amidst an arguably dismal landscape, labor practices began to shift in positive 
ways. While the late $19^{\text {th }}$ century saw major uprisings like the 1886 Haymarket Square Riot, where thousands of railroad workers rallied for an 8-hour workday, and the 1894 Pullman strike, mass mobilization regarding labor rights increased noticeably in the early $20^{\text {th }}$ century-particularly after grisly incidents like the 1911 Triangle Shirtwaist Factory fire in NYC (AFL-CIO, 1981). The changes were slow; even though the campaign for the 8-hour workday began in the $19^{\text {th }}$ century, it was not implemented until Henry Ford gave his factory employees 8-hour workdays in 1914 (Widrich, 2014). Throughout the 1930s and 1940s, the labor movement gained steam with the support of President Franklin D. Roosevelt and legislation passed during the New Deal.

In the 1950s, labor unions in the US reached their peak numbers as a percentage of the overall workforce before starting to decline as manufacturing slowly left the country. The decline of union membership in the 1970s is directly linked to current income inequality (Greenhouse, 2011). The Reagan Administration's severe anti-union stance in the 1980s further weakened organized labor, and union membership has been steadily declining in the US as manufacturing has been displaced to the Global South. Even as job growth has increased in the past few years, union membership has generally not. Many factors contribute to this: the anti-union laws enacted in some states, the expansion of manufacturing in Right-to-Work states, and an increase in restaurant and retail work (Greenhouse, 2013).

This is not to say that existing protections are sufficient or that the issues the labor movement sought to remedy are being addressed in other ways. Safety and health protections for workers have declined since organized labor's peak in the mid $20^{\text {th }}$ century (Cowie, 2006). Not only do traditional union models no longer apply to many current industries, but worker protections have disappeared in multiple sectors while protections have not emerged in new ones.

While the catastrophic effects of health and safety deregulation have not yet led to something on the scale of the Rana Plaza factory collapse in Bangladesh, many workers in the US are exposed to poor working conditions even under traditional frameworks of factory labor. Tales of the Hormel plant, where the lack of union contracts caused workers to become seriously ill after prolonged exposure to pig brain matter, continue to create headlines. The largest, most profitable companies are certainly not immune; some of the direst working conditions are in Amazon's warehouses, where employees engage in difficult physical labor in poor conditions for very low pay. Both examples point to workers' eroding rights (Genoways, 2011; McClelland, 2012). Even if manufacturing has moved overseas, low-wage work in places like meat processing plants and warehouses persists.

\section{Shift to Post-Fordism and the Birth of the Sharing Economy}

While the labor movement of the $19^{\text {th }}$ and early $20^{\text {th }}$ centuries helped to shape the 8 hour workday and other worker protections through unions, contracts, and collective 
bargaining, these models do not necessarily apply now. Alongside structural, political, social, and legal reasons for union membership's decline over the past several decades, labor itself has also shifted. Additionally, there is an increase in part-time, independent, contract, freelance, or free labor in the form of internships and unpaid repurposing of information. As manufacturing has declined in the United States, computer-based jobs have grown exponentially, too. Gilles Deleuze links the emergence of computer technologies to new forms of control that are less defined by structure but just as insidious as the strict hierarchies of the industrial era. In his short essay, "Postscript on the Societies of Control," Deleuze marks the shift from a disciplinary to a control society. In a control society, power is not found within institutions as in a Foucauldian disciplinary society. Instead of using enclosure and forced molding in order to maintain power, "controls are a modulation, like a self-deforming cast that will continuously change from one moment to the other, or like a sieve whose mesh will transmute from point to point" (Deleuze, 1992). Power in a control society is able to adjust itself, constantly shifting in order to fit the present context. It is not constricted by calcified structures, but instead exists in network form. For example, managers may allow their employees to work flexible hours, or even to work from home, but still require them to check in over email at all times. In the transition from a disciplinary society to a control society, "the corporation has replaced the factory, and the corporation is a spirit, a gas" (Deleuze, 1992). Even if control has become decentralized, it does not mean power hierarchies no longer exist. Constant computerized communication keeps the various nodes of the network in check.

Post-Fordism, which marks the shift away from productive factory labor and manufacturing to a postindustrial economy, is a hallmark of the control society. Instead of producing goods in the industrial-age Fordist factory, workers instead engage in immaterial, free, cognitive, and affective forms of labor. In post-Fordism, aspects of the shift away from industrial labor that seem potentially liberating (i.e. the lack of strict structural hierarchies) are really new forms of control and domination. For example, while part-time workers may on some level enjoy their flexible hours, they are also subject to the scheduling whims of their employers. As Virginia Postrel (2014) notes, female pharmacists enjoy their flexible schedules and short work hours because they also receive a high hourly wage. For low-wage workers, part-time hours and required flexibility means that they are often scrambling to work enough hours to make a living and are more willing to acquiesce to their employers' scheduling demands.

Post-Fordism and the control society have led to the prevalence of "digital labor," or the online activities we engage in that portend a slippage between work and leisure (Scholz, 2012). This current system is a far cry from the drudgery and endless mechanical motions of the Fordist factory. Still, our bosses can tell us that we must communicate. For example, journalists must start Twitter accounts to amass followers interested in their work, and the proliferation of smartphones makes it explicitly or implicitly imperative to immediately respond to emails even on the weekends or in the evening hours. Melissa Gregg (2011) has noted an array of emotional, affective, and 
interpersonal repercussions of our connectedness. For all of the changes brought about by contemporary connectedness, she also argues that white-collar workers have "sold themselves" in terms of their personalities since at least the Fordist era. Sociologists like William H. Whyte and C. Wright Mills studied white-collar workers in the mid $20^{\text {th }}$ century, detailing how Dictaphones allowed businessmen to work from home and describing the importance of off-hour networking for workers, leading Gregg (2011) to note that "technology has long facilitated particular work styles and preferences, especially for a business demographic" (p. 9).

What is it that separates Fordist-era labor from that being done today? One new development is the ubiquity of computer-based jobs and tasks. As Bifo Berardi (2009) claims, "work is performed according to the same physical patterns: we all sit in front of a screen and move our fingers across a keyboard. We type" (p. 74). Everyone may perform mental labor using the same gestures, but we are all highly specialized and cannot trade places; an attorney and a travel agent cannot switch jobs despite using the same devices. Maurizio Lazzarato (1996) defines immaterial labor "as the labor that produces the informational and cultural content of the commodity." In the production of the cultural content, "immaterial labor involves a series of activities that are not normally recognized as 'work' - in other words, the kinds of activities involved in defining and fixing cultural and artistic standards, fashions, tastes, consumer norms, and, more strategically, public opinion" (Lazzarato, 1996). While this work used to be the purview of the intelligentsia or the bourgeois classes, everyone in the new economy is caught up in this web of immaterial production. Although technology makes the production of immaterial labor more accessible, it does not relieve the difficulty with which people have in monetizing such acts.

Numerous scholars and cultural observers have noted that white-collar labor practices today in many ways diverge from those in the mid-twentieth century (Ross, 2004; Neff, 2012; Gregg, 2011). Rather than starting at one company and staying on until retirement, individuals now frequently change jobs and careers several times over the course of a lifetime both out of choice and necessity. In the 1950s and early 1960s, whitecollar Americans worked at one company for life, but this began to shift in the mid 1960s as entrepreneurship became more common. While entrepreneurship has often been interwoven with technology, the 1990s dotcom boom solidified that narrative in the public consciousness. Gina Neff (2012) defines the era as a moment when "venture labor" became valued and the news media "celebrated and naturalized these economic risks by urging a casual, even positive, attitude toward losing one's job. Such portrayals framed economic and financial risks as inevitable, necessary, and beneficial for one's career and companies, reinforcing cultural messages about the attractiveness of risk" ( $p$. 3). Because of discourses about entrepreneurialism during the dotcom era, individual risk became "cool," even if it was recognized that employee risk is not the same thing as corporate risk (Neff, 2012, p. 4). 
After the collapse of the dotcom bubble in 2000, sharing and collaboration emerged as the new entrepreneurial spirit. Tim O'Reilly popularized the notion of Web 2.0 in 2004 , arguing that the next wave of the Internet would be grounded by open source projects, where anyone could access a particular code and make alterations to it. In the rhetoric of Web 2.0, users work as co-developers and companies harness the collective intelligence of site visitors ( $\mathrm{O}^{\prime}$ Reilly, 2005). Many thought leaders and scholars including, notably, Clay Shirky (2008) and Yochai Benkler (2006) - envisioned a technological landscape that would enable unprecedented collaborative production, increased worker autonomy, and the rise of individual voices. Tools like Wikipedia were touted as indicators of the future, but the data-centric advertising and marketingoriented business practices that emerged out of the tools of that era suggested a different set of values and trade-offs instead.

\section{Transformation of the Worker and the Workspace}

While the technology sector often highlights flexibility, collaboration, ubiquitous computing, and the new entrepreneurial spirit as freeing for workers, these normative values come with trade-offs that are not universally appreciated. Workers' hours are not necessarily the typical 9-5 positions that were common decades ago; instead, many workers are expected to work long hours even if those hours are flexible. In the $19^{\text {th }}$ and early $20^{\text {th }}$ centuries, individuals were either considered employed or unemployed; now, there is an entire gray spectrum of employment possibilities. Many workers now have flexible, part-time hours, are self-employed, or perform work as freelancers, interns, temps, or contractors, no longer working for just one corporate entity. In fact, in 2005, these flexible laborers composed over one third of the US workforce (Freelancer's Union, 2011, p. 1). Technology is also at the center of this shift in the labor force: "Additionally, technological advances have fostered the emergence of freelancers and other independent workers who can easily complete tasks away from a physical office space while remaining in touch with clients using cell phones and laptops" (Freelancer's Union, 2011, p. 2). Many so-called "free agents" choose this lifestyle because of its enhanced "freedom and flexibility," but others adopt these practices because they have no alternative (Kelly Media, 2011).

According to a study by Kelly Media (2011), 44\% of workers in the US now classify themselves as "free agents" while only 26\% identified as such in 2008 (p. 4). Many of the new, flexible workforce members are retirees who still need or desire part-time employment. Roughly half of individuals who are close to retirement plan on seeking outside employment in addition to their retirement benefits, but the largest percentage of free agents are career freelancers. Many of these workers are highly skilled: 35 percent have a MA degree and 77 percent have a technical or professional skillsets (Kelly Media, 2011, p. 13). Part-time businesses have expanded in the past few years, adding 141 billion a year to the US economy. According to the Internet Association, " [u]p to 80\% of part-time business owners describe their businesses as providing freedom, flexibility, 
and fulfillment. A diverse array of part-time small businesses utilize the Internet (i.e., collectors, artisans, technical consultants, musicians, bakers/chefs, web designers, educators, carpenters)" (2013). This new flexibility is often touted as providing workers freedom and yet this arrangement also benefits businesses, which "recognize the flexibility and cost savings that contractors provide them" (Internet Association, 2013). But flexibility also means a lack of benefits and protections. Some workers are now employed part-time because they are forced into these positions and employers go out of their way to prevent workers from reaching full-time status in order to withhold benefits.

For those who choose this approach to work, it can indeed be quite freeing. Freelancing enables a variety of childcare solutions (Levy, 2014), for example, and allows workers to assert some means of control over when, where, and how they work (MBO Partners, 2013, p. 6). Despite the fact that some "free agents" praise the work/life balance afforded by this type of flexible work, as well as lower stress levels and the various available ways to advance one's career, there are also drawbacks to this new labor structure. There are fewer health care options and less job security and, according to Kelly Media's (2011) study, many millennials claim that they are in these flexible arrangements because they could not find full-time work. Comparatively, members of Generation X are worried about their long-term future and retirement. Furthermore, while some part-time and freelancer labor is highly desirable, much more consists of low-prestige, minimum wage work without benefits or sick days, as it is in the fast food service industry or with in-home cleaning and childcare services. While some aspects of the shift to freelance or independent labor can be framed as a matter of individual choice, there are also structural factors at play. Forbes and other news outlets have clamored around the idea of freelance laborers outpacing the rest of the economy, but many independent workers still work for other companies and are not truly selfemployed.

Some researchers are also skeptical that freelance or independent labor is a new phenomenon in the United States, or that the trend is growing as swiftly as some reports claims. While the MBO Partners (2013) report states that 14.4 million Americans were self-employed in January of 2014, this is actually the same number of self-employed Americans there were in January 2000. The numbers have remained basically the same over the past fourteen years and, in fact, "the long-term trend in the percentage of workers who are self-employed actually appears to be downward" (Fox, 2014).

There is some evidence that the narrative of increased independence and heightened levels of self-employed is misleading. There have always been self-employed people in American society, and independent workers are not a new phenomenon. For instance, in the $19^{\text {th }}$ century, many individuals were farmers while "[o]thers were tradespeople, professionals, hands-on service providers, and such. Even after the huge economic transformations wrought by the first half of the $20^{\text {th }}$ century, the self-employed still made up more than $19 \%$ of the workforce in 1949, according to the U.S. Bureau of 
Labor Statistics (BLS), compared with just over 10\% today. (The BLS data series on selfemployment starts in 1948)" (Fox, 2014). According to Fox, one problem in tracking this is that modern surveys of freelance laborers use the same methods available in 1950, which may not accurately reflect the shifts that have occurred.

One aspect of labor practices that appears to relatively recent is the blurring line between leisure and labor. There are historical examples of these practices comingling, or of hobbyists being paid a wage, and some workers may feel that they enjoy their work to the point of not caring about regular hours, benefits, or other things that constitute fair labor practices. In fact, some laborers may not want to be paid for their work at all. In Network Culture, Tiziana Terranova describes free labor as "this excessive activity that makes the Internet a thriving and hyperactive medium," which is "a feature of the cultural economy at large, and an important, yet unacknowledged, source of value in advanced capitalist societies" (p. 73). As labor and production become increasingly immaterial, free labor becomes a central part of the digital economy. To keep a website operational, it is best for users to have a chance to build the site themselves, through their volunteer labor. Around fifteen thousand volunteers kept AOL running, and the open-source software movement requires the free labor of Internet tinkers (Terranova, 2004 , p. 91). Given the high levels of volunteer labor who knowingly give their time and energy to corporate entities, it is overly simplistic to argue that these digital workers are merely being exploited. Only a few of the AOL volunteers turned against the company, after all. While they did not receive great financial rewards for their work, they did receive "the pleasure of communication and exchange" (Terranova, 2004, p. 91). As Terranova (2004) claims, "the volunteers for America On Line, the netslaves and the amateur web designers did not work only because capital wanted them to, but they were acting out a desire for affective and cultural production which was none the less real just because it was socially shaped" (p. 77). While they were not compensated in cash, the volunteers derived pleasure from their labor. This enjoyment was not a result of false consciousness; they were not tricked into performing this work, but did so of their own accord and for their own set of reasons. Other forms of crowdsourced labor are also unpaid, such as those who contribute to sites like Wikipedia or who provide reviews or comments on sites like Amazon or help fuel the algorithms behind Facebook's advertising business by interacting with friends and family. These workers are affectively productive even if they are not engaged in traditional forms of wage labor.

At the heart of the technology industry, the incentive to work 80 hours a week is heightened by a sense of pleasure in work. Corporations like Twitter and Google have young employees and provide leisure activities in order to encourage employees to stay long hours. They also provide beds, gyms, and fully stocked cafeterias, making it so employees never have to go home (Stewart, 2013). In many ways, the office of the $21^{\text {st }}$ century is unrecognizable from the mid $20^{\text {th }}$ century office with its focus on strict hierarchical structures and monolithic regimens, such as environments documented in C. Wright Mills' study of white collar workers in the 1950s. In his book Cubed, author 
Nick Saval examines the history of the office space itself rather than focusing on its workers. Saval traces the rise of the clerk in the $19^{\text {th }}$ century thanks to the formation of the factory and its associated managerial office. The desk gave way to the cubicle, which is now replaced by the electrical outlet, possibly in a coffee shop, other public space, home office, or in a decentralized workspace couch: "There are no more desks and no more offices; instead, there are spaces with couches and pinball machines and, in the kitchen, refrigerators full of coconut water and edamame, and everyone is equal, and innovating" (Lepore, 2014). When the workplace is full of leisure activity spaces, good food, and decentralized workspaces, going home may seem less appealing.

But there is a darker side to this new freedom and the blurring of leisure and work: "Leisure may be over, but that's only because when your office is a cloud it follows you everywhere. The arrangement that began in the nineteenth-century factory and lived on through the twentieth-century office may end soon; if so, the two-century-long separation of home and work will turn out to have been a historical anomaly. Work will no longer be a place, and home no longer an escape" (Lepore, 2014). As physical divisions between work and play, or boss and employee, fade, workers may find it harder to negotiate the boundaries of the work day and workspace.

\section{Crowdwork as the New Assembly Line}

Microtasking platforms allow individuals to get paid for every small, atomized task they complete instead of receiving a salary or even an hourly wage. This is a new form of piecework, but instead of the Taylorist or Fordist assembly line, workers perform tasks on their home computers or use their mobile phones in order to sign of up for apps that will lead to short-term, task-based gigs: "For example, anyone with access to the Internet can perform micro- tasks on the order of seconds using platforms such as Amazon's Mechanical Turk, while more skilled workers can complete multi-hour tasks on professional online marketplaces such as oDesk or work for months to solve R\&D challenges on open innovation platforms (e.g. Innocentive). Incentives and work structures also vary tremendously, ranging from crowdsourcing contests awarding prizes to winners (e.g. programming tasks on Topcoder) to micro-labor platforms that pay workers per task" (Kittur et al., 2013). Task-based jobs require varying degrees of expertise and provide different benefits according to skill level.

While the pay rates for different types of tasks vary tremendously, all of these taskbased workers rely on their reputation as a metric for acquiring future work. On Mechanical Turk, workers are rated according to how quickly and consistently they complete tasks. If they receive poor ratings, they may be blackballed from the system. The companies that use Mechanical Turk want to make sure that the microtask workers are reliable, thus ensuring quality data and returns: "Many researchers who use MTurk are concerned about the quality of data they can get from their MTurk workers. Can we trust our "Turkers" to read instructions carefully, answer all the questions candidly and 
follow our procedures prudently? Moreover, are there specific types of workers we should be targeting to ensure high quality data?" (Paolacci, 2014).

Lilly Irani (2012) discuses the ways that Mechanical Turk benefits businesses, in that temporary workers are replaced by thousands of individuals working from home. These workers are "largely invisible cognitive pieceworkers. Keeping workers at a distance here, by mediating them through anonymizing spreadsheets and Application Program Interfaces (API) - allowed Amazon to retain its existing divisions of labor and organizational practices" (Irani, 2012). Rather than having managers directly contact workers and guide them, 60,000 people are managed through digital traces, which in turn determine their ratings, whether or not they are paid, and their ability to continue working for Mechanical Turk. These workers, however, have no way of seeking recourse if they feel their reviews are unfair or if they are ejected from the system. In general, these new kinds of crowdwork are susceptible to various labor abuses, such as the practice of asking workers to complete questionable, illegal, or grey-market tasks, such as "gold-farming" (amassing in-game money and selling it to players for cash) in video and computer games. These workforces are in many ways an unregulated kind of Taylorist assembly line, where piecemeal work replaces skilled labor (Kittur et al., 2013, p. 2-3). There are new opportunities for workers and companies thanks to this crowdwork, but there are also serious risks. Because of the structure of this kind of labor, workers are alienated from each other and their employers, while employers may view their employees as "exchangeable and untrustworthy, having low or static skill sets and strong motivations to shirk [their duties]" (Kittur et al., 2013). The system's lack of transparency, the invisibility and atomization of its workers, and the lack of contact between managers and workers means that workers are extremely vulnerable. How might this system take already precarious laborers and render them even more at risk?

Similar to this kind of crowdwork, the sharing economy is also in many ways informal, which means that workers may not receive benefits and are not generally treated as full employees. While there are some "commons-oriented peer production and greed-free companies" in this category, the sharing economy is mostly determined by huge companies like Airbnb, Lyft, and Uber, not by more progressive entities (Scholz, 2014). Sarah Kessler (2014) examines the "micro entrepreneur" economy. Rather than working for a company, the idea is that smartphone apps, programs, and websites will connect individuals to customers who want specific tasks done. Through these sites, you can have a stranger in your house for a night, give him a ride, get his dry cleaning, or help him put together his bookshelves. TaskRabbit is one of these sites and revolves around a market of workers who engage in random tasks for strangers in exchange for pay. But even if this sounds like it's open to everyone and can yield individuals a plethora of small-scale job opportunities, Kessler (2014) notes that she is rejected on her bids for jobs because she is asking too high of a price: "Because of the way TaskRabbit works, job posters can easily find the people willing to work for the least amount of money." Many of the jobs pay less than minimum wage, particularly if the time searching and applying for jobs and commuting to and from the tasks are factored in. 
Companies will advertise success stories of individuals who make their entire livings and careers from these microbusinesses, but these workers are not considered employees. If individuals work for companies like Postmates, Lyft, or TaskRabbit, they are considered microbusiness owners. TaskRabbit allows individuals to hire people as part-time workers, but they are still neither the employees of the individual nor of TaskRabbit. As a result, sharing economy companies claim no responsibility for the welfare of the person making deliveries, driving customers, or performing tasks in other people's homes. Furthermore, they are not legally obligated to do so.

There is still a power differential and structural divide between the people who turn to a crowd-sourcing platform to make extra money and the company employees who run the platform. The latter make good money and receive full benefits, but this is not the case for the people who use offer their services on the site. Kessler (2014) notes that "[w]hen I later visit the web page that Postmates uses to recruit employees, I can't help but notice that it boasts that Postmates pays $100 \%$ of its employees' medical, dental, and vision insurance premiums." But by "employees" Postmates is only referring to its executives, designers, and other full-time staff, not to the ones who are making deliveries. Some of this is starting to change, however, as lawsuits force companies like Lyft to insure their drivers between rides (Lawler, 2014; Kessler, 2014).

But for all of this apparent exploitation, some people also take these jobs because they enjoy them. Many of them are fond of the supplemental income they earn, but they also feel that they are helping others. According to Kessler, one woman who works for TaskRabbit claims that she would never work for TaskRabbit full time, since it would never be enough money to live on, but that she enjoys helping other people out with random tasks. These jobs are contingent upon building relationships with other human beings, learning their personal life stories, and being exposed to personal items in others' homes or cars. However, the enjoyment that task-based workers espouse may be performative. According to Avi Asher-Schapiro (2014), Uber drivers in Los Angeles tell passengers that they enjoy the job in order to protect themselves against receiving a low rating. One driver said, "We just sit there and smile, and tell everyone that the job's awesome, because that's what they want to hear." They are actually dissatisfied with the conditions of their labor and another driver told Asher-Schapiro, "Uber's like an exploiting pimp." Especially for drivers who are immigrants or otherwise precarious, the more utopian aspects of the sharing economy may not apply. Instead, they may hide their mistreatment by Uber so as not to offend customers. According to yet another driver, the sunny platitudes voiced by Uber's leadership are contradicted by the company's view of its workers: "They think we are a bunch of losers who can't find better jobs... That's why they treat us like robots - like we are replaceable" (AsherSchapiro, 2014).

The importance of selling oneself is a key aspect of this kind of piecemeal or contract work, particular because of the large power differential between management and workers and because of the perceived disposability of workers. In order to be 
considered for future jobs, workers must maintain their high ratings and receive generally positive reviews or they may be booted from the system. Nancy Baym's definition of relational labor seems relevant to this kind of arrangement, where emotional appeals, connection, interaction, and communication are endemic to acquiring and maintaining jobs. Relational labor is defined by "ongoing communicative practices and skills of building and maintaining interpersonal and group relationships" (Baym et al., 2014). Building and retaining relationships that makes this feel more like interactions with friends or family rather than with customers, but the apparent easiness of this kind of exchange may obfuscate deeper structural inequalities.

\section{How to organize and protect disparate workers}

If microtaskers are not defined as employees but as independent agents and many digital laborers don't see their practice as work, how can unions reach or organize these people? They can't bargain over things like benefits and wages because these workers are not even defined as such in the first place. Furthermore, if employees change jobs every few years or engage in minute tasks on crowd sourcing sites, union membership and contracts with individual companies will not be stable or viable. Instead, individuals might do piecework for five companies at once, perhaps changing out one company for another every few months. The lack of employment stability is another reason for the decline of traditional unions, as well as the fact that much of this labor and the laborers behind it are mostly invisible.

While many scholars and journalists have focused on the plight of white-collar workers in the post-Fordist era, marking the shift to a 24-hour work day as smartphones and other devices enter the domicile and as the lines between pleasure/play and labor blur, blue-collar jobs are also part of the new labor landscape. Google engineers may choose to spend their waking hours at work, munching on granola and using the gym facilities when they choose to take breaks, but not all of those who appear to be Google employees have equal access to the various perks and benefits the company offers. There is a very visible division between "real" Google employees and the Googleplex workers, and the two workforces also look very different. Google's lack of diversity has recently faced media scrutiny, as the company disclosed that $70 \%$ of its workforce is male and that $91 \%$ of workers are white or Asian (Lafrance, 2014). Andrew Wilson's 2011 short film "Workers Leaving the Googleplex" captured the racial divide between tech employees at Google and the often African American and Latino workers who perform janitorial or food service duties at the Googleplex (Newman, 2011). Thousands of temps, vendors, and contractors - marked by their red badge - depend on their $3^{\text {rd }}$ party employer to negotiate benefits on their behalf, and are not tallied as part of this workforce As a result, the benefits vary wildly. It is in fact possible, after factoring in commute time and low wages, to appear to work for Google and still barely make enough money to get by (Tiku, 2013). Much of what's at stake is that many companies - 
not just in the technology industry - rely heavily on third party vendors to provide cheap contract labor that is treated separately than the core workforce.

This has been happening in other industries for a while. For instance, cab drivers in Chicago had to fight against being labeled as independent contractors rather than employees: "The lawsuit says that in addition to no overtime pay or minimum wage, drivers working as independent contractors don't always have coverage for workers' compensation insurance or protection against discrimination" (Smith, 2014). Recently, Uber and Lyft drivers have begun fighting against the notion that they are not full employees, but micro entrepreneurs. While Uber drivers appreciate their flexible work hours, they do not enjoy the inherent instability of the job. Uber regularly changes its commission rates, meaning that drivers' monthly incomes fluctuate greatly. Uber is in many ways superior to traditional taxi services in that it is more accessible; and is faster, easier, cheaper, and cleaner. Yet, disrupting (and possibly soon usurping) the traditional taxi industry does not necessarily mean that Uber drivers are free from the same structural problems inherent to the system: “Uber's revolution is not actually its technology but its market power. It has disrupted the cab industry in ways so many others can only dream of by leveraging the labor of thousands of workers who are exceptionally underprotected" (Cagle, 2014). Flexibility also means a lack of benefits and protections.

As workers start to voice collective concerns, such as the Uber drivers did, new types of unions are emerging to re-imagine collective bargaining and rights in the networked era; in fact, the Drivers Network is a new union that formed for Lyft and Uber drivers. Meanwhile, long-standing unions are trying to rethink and modernize their organizing efforts, too. While most white-collar employees were not unionized in the $19^{\text {th }}$ and early to mid $20^{\text {th }}$ centuries, labor unions now attempt to unionize many different types of white-collar laborers. Unions like the AFT and the UAW have looked to new kinds of workers to organize, such as graduate student employees, postdocs, and adjunct professors, which now comprise up to $75 \%$ of the academic workforce (Steiger, 2013). According to the Coalition on the Academic Workforce, adjunct professors are disproportionately female (61\%) (Steiger, 2013). According to the New Faculty Majority's (2014) websites, most people of color who are in academia hold part-time positions and, in a survey of adjunct professors, those who self-identified as black received lower wages than any other ethnic or racial group. As different formerly whitecollar sectors move to a part-time model, women of color are especially vulnerable to the new low wages, lack of benefits, and lack of workplace protections. Traditional labor unions as well as newer groups like the New Faculty Majority and the Coalition on the Academic Workforce are attempting to mitigate these structural inequalities.

Even with these changes, however, there are large swathes of the labor force that are not currently and are unlikely to ever be covered by traditional union organizing. For example, SEIU is attempting to unionize security guards across Silicon Valley (Tiku, 2013), but their union model may no longer be viable for employees who work at 
multiple jobs or who engage in online piecework in spaces like Mechanical Turk or oDesk. It is difficult to organize a dispersed, temporary workforce and garner a strong union contract. Furthermore, if workers are anonymous, atomized, disparately located, and without a common workspace, it is far harder for them to self-organize. As more people enter this sort of work arrangement, traditional trade unions may not be the sole solution.

Recognizing the difficulty in organizing these workers, some activists have begun to look for other interventions to protect marginalized laborers en masse. One proposed way of addressing inequality and protecting workers in the post-Fordist age is to focus on minimum wage increases. The majority of fast-food workers are women of color, many of whom have families to support, so the abysmally low minimum wage affects them disproportionately (Kohn, 2013). Because many service workers are not classified as full-time employees but referred to as temporary workers, many groups, including 15 Now, Socialist Alternative, Jobs with Justice, Fight for 15, and even some traditional labor unions like SEIU are advocating for an increase in minimum wage. In May 2014, Seattle's city council passed a bill that will raise the city's minimum wage to 15 dollars an hour over the next few years (Gupta, 2014). Recently, hotel workers in Los Angeles received a 15-dollar hourly wage after a city council vote (Carroll, 2014). This more holistic approach can be hugely beneficial for workers, but such efforts raise questions about who should be advocating on behalf of whom and how such efforts should be made sustainable. Mechanical Turk's ability to circumvent existing minimum wage laws and the deplorable work conditions in Amazon's warehouses or in Hormel's factories, for instance, means that even a minimum wage increase will not necessarily protect workers from exploitation. This is why some groups involved in the "15 movement" are pushing not only for a minimum wage increase, but for service employees' right to collectively bargain.

In considering what the future of labor protection looks like in a networked era, there are often more questions than answers: are there other legal and political infrastructures available for handling some of the inequalities built into flexible labor? How can these issues be addressed through legislation?

What constitutes fairness when it comes to this kind of labor? And what happens when the content produced through digital labor is called into question or even directly used against the producer? In a recent case, a hotel was fining newlywed couples who left negative Yelp reviews (Griswold, 2014). Since hotels and other places of business depend on positive Yelp ratings to attract new customers, and customers are encouraged to provide free digital labor in writing reviews, what are the legal ramifications of encouraging positive reviews or punishing customers for negative ones? Beyond legal questions, what are the ethics? Can consumers be held responsible for inaccurate reviews? If riders give Uber or Lyft drivers low ratings, this could seriously jeopardize drivers' livelihoods, but customers may not even realize this. Also, accurate negative reviews of businesses (or, in the case of Uber and Lyft, dangerous drivers) can help 
prevent other customers from having the same bad experience. Still, what are the ethics of these new kinds of transactions? Do reviewers and users have responsibilities to the micro entrepreneurs they hire for particular tasks?

It is difficult to distinguish between work and pleasure when the same tools and devices are used for both. Many things that count as digital labor, however, are not associated with pleasure nor are they highly paid. There are many jobs that have emerged as part of the digital economy, like Mechanical Turk, that can leave workers with poor work terms, low wages, and no benefits. What can be done to make crowd work more effective for both employees and employers? What can be done to protect these new atomized, home-based, and largely invisible workers?

The future of fair labor remains uncertain, but critical. The questions raised by new mechanisms of work cannot simply be about what is or is not legal, but must instead be rooted in an ethical and moral framework for defining labor.

\section{Acknowledgments}

This document was produced as a part of the Future of Work Project at Data \& Society Research Institute. This effort is supported by the Open Society Foundations' U.S. Programs Future of Work inquiry, which is bringing together a cross-disciplinary and diverse group of thinkers to address some of the biggest questions about how work is transforming and what working will look like 20-30 years from now. The inquiry is exploring how the transformation of work, jobs and income will affect the most vulnerable communities, and what can be done to alter the course of events for the better.

We are grateful to Patrick Davison, Tim Hwang, Rosa Jurjevics, Karen Levy, and Seth Young for their help with different aspects of this project.

\section{Bibliography}

AFL-CIO. (1981).“A Short History of American Labor.” American Federationist, March 1981.

http:/ / www.albany.edu/history/history316/LaborMovementHistory1.html

Asher-Schapiro, Avi. (2014). "Against Sharing." Jacobin, September 19, 2014.

https: / / www.jacobinmag.com/2014/09/against-sharing/

Baym, Nancy, Radhika Gajjala, Katherine Sender \& Beretta Smith-Shomade. (2014). "Conference Plenary." Columbia, MO: Console-ing Passions, April 10, 2014.

Benkler, Yocahi. (2006). The Wealth of Networks. New Haven, CT: Yale University Press.

Berardi, Franco. (2009). The Soul at Work: From Alienation to Autonomy. Los

Angeles, CA: Semiotext(e).

Boltanski, Luc \& Eve Chiapello. (2005). The New Spirit of Capitalism. London: Verso.

Cagle, Susie. (2014). "To get a fair share, sharing-economy workers must unionize." Aljazeera America, June 27, 2014. http:/ / america.aljazeera.com/opinions/2014/6/uber-sharingeconomyunionstaxis.html

Carroll, Rory. (2014). “Los Angeles hotel workers win \$15 minimum wage after city council vote," The Guardian, September 25, 2014. 
http:/ / www.theguardian.com/world/2014/sep/25/los-angeles-hotel-minimum-wage-citycouncil

Cowie, Jeff. (2006). "A Brief History of the Labor Movement." [radio broadcast] Washington D.C.: NPR News. September 3, 2006.

Dean, Jodi. (2010). "Affective Networks." MediaTropes eJournal, 2(2), 19-44.

Deleuze, Gilles. (1992). "Postscript on the Societies of Control." October, 59(Winter), 3-7.

Fox, Justin. (2014). “Where are All the Self-Employed Workers?" Harvard Business Review, February 7, 2014. http:/ / blogs.hbr.org/2014/02/ where-are-all-the-self-employed-workers/

Freelancer's Union, The. (2011). “America's Uncounted Independent Workforce.” http:/ /fures.org/pdfs/advocacy/2011_Counting_the_Independent_Workforce\%20Policy_Brief.pdf

Genoways, Ted. (2011). "The Spam Factory's Dirty Secret.” Mother Jones, July / August 2011. http:// www.motherjones.com/politics/2011/06/hormel-spam-pig-brains-disease

Greenhouse, Steven. (2011). "Labor's Decline and Wage Inequality." Enconomix Blog, The New York Times, August 4, 2011. http:/ / economix.blogs.nytimes.com/2011/08/04/labors-declineand-wage-inequality $/$ ?_php=true\&_type $=$ blogs\&_r $=0$

Greenhouse, Steven. (2013). "Share of the Work Force in a Union Falls to a 97-Year Low, 11.3\%." The New York Times, January 23, 2013.

http:/ / www.nytimes.com/2013/01/24/ business/ union-membership-drops-despite-jobgrowth.html?_r=0

Gregg, Melissa. (2011). Work's Intimacy. Cambridge, MA: Polity.

Griswold, Alison. (2014). "Is It Legal to Fine Customers for Negative Online Reviews?" Slate, August 5, 2014.

http://www.slate.com/blogs/moneybox/2014/08/05/union_street_guest_house_is_it_legal _to_fine_consumers_for_negative_online.html

Gupta, Arun. (2014). "Learning from a Socialist in Seattle," Al Jazeera America, May 21, 2014. http:/ / america.aljazeera.com/opinions/2014/5/seattle-minimum-

wage15nowsocialismkshamasawantinequality.html

Internet Association, The. (2013). "The Internet Association Releases Part-Time Business Economic Report: Internet Fuels Part-Time Businesses; Adds \$141 Billion to U.S. Economy." October 9, 2013. http:/ / internetassociation.org/100913part-timebusinessreport/

Irani, Lilly. (2012). "Microworking the Crowd." LIMN, 2, March 27, 2012. http:/ / limn.it/microworking-the-crowd/

Kelly Media. (2011). “The New Workforce: Insights into the Free Agent Workstyle." Kelly Services. http:/ / www.kellyservices.com/US/Careers/Candidate-Resource-Center/JobTrends/The-New-Workforce_-Insights-into-the-free-agent-workstyle/

Kessler, Sarah. (2014). "Pixel and Dimed: On (not) getting by in the gig economy." Fast Company, March 18, 2014. http:/ / www.fastcompany.com/3027355/ pixel-and-dimed-on-not-getting-byin-the-gig-economy

Kittur, Aniket, Jeffrey V. Nickerson, Michael S. Bernstein, Elizabeth M. Gerber, Aaron Shaw, John Zimmerman, Matthew Lease, \& John J. Horton. (2013). "The Future of Crowd Work." San Antonio, TX: 16th ACM Conference on Computer Supported Cooperative Work (CSCW 2013).

Kohn, Sally. (2013). “Feminism's Sticky Fast-Food Floor." The Daily Beast, August 29, 2013. http:/ / www.thedailybeast.com/witw/articles/2013/08/29/ forget-the-glass-ceiling-fastfood-has-a-sticky-floor-for-low-wage-female-workers.html

Lafrance, Adrienne. (2014). “Tallying Female Workers Isn't Enough to Make Tech More Diverse." The Atlantic, August 11, 2014.

http:/ / www.theatlantic.com/technology/archive/2014/08/ what-good-is-all-this-tech- 
diversity-data-anyway/375829/2/

Lawler, Ryan. (2014). "On-Demand Ridesharing Startup Lyft Adds Insurance Between Rides." Tech Crunch, March 13, 2014. http:/ / techcrunch.com/2014/03/13/lyft-insurance-betweenrides/

Lazzarato, Maurizio. (2006). "Immaterial Labor." In Paolo Vimo (Ed.), Radical Thought in Italy: A Potential Politics (Theory Out Of Bounds). Minnesota, MN: University of Minnesota Press.

Lepore, Jill. (2014). "Away from My Desk: The Office from Beginning to End." The New Yorker, May 12, 2014. http:/ / www.newyorker.com/magazine/2014/05/12/away-from-my-desk

Levy, Sandra. (2014). "A New Generation of Dads Juggles Work and Childrearing." Healthline News, June 27, 2014. http:/ / www.healthline.com/health-news/dads-taking-on-morechildcare-responsibilities-062714

MBO Partners. (2013). “State of Independence In America: Third Annual Independent Workforce Report." http:/ / info.mbopartners.com/rs/mbo/images/2013-

MBO_Partners_State_of_Independence_Report.pdf

McClelland, Mac. (2012). “I Was a Warehouse Wage Slave.” Mother Jones, March/April 2012. http:/ / www.motherjones.com/politics/2012/02/ mac-mcclelland-free-online-shippingwarehouses-labor

Neff, Gina. (2012). Venture Labor: Work at the Burden of Risk in Innovative Industries. Cambridge, MA: MIT Press. http:/ / www.com.washington.edu/faculty/assets/neff_venture labor_excerpt.pdf

New Faculty Majority. (2014). “Facts about Adjuncts.” Accessed October 1, 2014. http:/ / www.newfacultymajority.info/facts-about-adjuncts/

Newman, Nathan. (2011). "Is Silicon Valley Adding to the Jobs Depression for Blacks and Latinos?" The Huffington Post, December 20, 2011. http:// www.huffingtonpost.com/nathannewman/is-silicon-valley-adding-_b_1159635.html

O'Reilly, Tim. (2005). “What is Web 2.0: Design Patterns and Business Models for the Next Generation of Software." September 30, 2005. http: / / oreilly.com/web2/ archive/ what-is-web20.html

Paolacci, Gabriele. (2014). "Review of MTurk as a Participant Pool." Experiemental Turk: A blog on social science experiments on Amazon Mechanical Turk, July 10, 2014.

http:/ / experimentalturk.wordpress.com/2014/07/10/review-of-mturk-as-a-participantpool/

Postrel, Virginia. (2014). “Why Being a Part-Time Worker is Miserable.” Bloomberg View, July 29, 2014. http:/ / www.bloombergview.com/articles/2014-07-29/ why-being-a-part-time-workeris-miserable

Ross, Andrew. (2004). No Collar: The Humane Workplace and its Hidden Costs. Philadelphia, PA: Temple University Press.

Saval, Nikil. (2014). Cubed: A Secret History of the Workplace. New York, NY: Doubleday.

Scholz, Trebor (2012). "Introduction." In Trebor Scholz (Ed.), Digital Labor: The Internet as Playground and Factory. New York: Routledge.

Scholz, Trebor. "The Politics of the Sharing Economy." journalisms, May 19, 2014. http:/ / collectivate.net/journalisms/2014/5/19/the-politics-of-the-sharing-economy.html Shirky, Clay. (2008). Here Comes Everybody. New York, NY: Penguin Books.

Smith, Mitch. (2014). "Suit: Taxi Drivers Should be Considered Employees." The Chicago Tribune, March 26, 2014. http:/ / articles.chicagotribune.com/2014-03-26/ news/ chi-suit-taxi-driversshould-be-considered-employees-20140326_1_taxi-drivers-yellow-cab-taxi-industry 
Steiger, Kay. (2013). “The Pink Collar Workforce of Academia.” The Nation, July 11, 2013. http:/ / www.thenation.com/article/175214/academias-pink-collar-workforce

Stewart, James B. (2013). "Looking for a Lesson in Google's Perks." The New York Times, March 15, 2013. http:/ / www.nytimes.com/2013/03/16/business / at-google-a-place-to-work-andplay.html

Terranova, Tiziana. (2004). Network Culture: Politics for the Information Age. London: Pluto Books.

Tiku, Nitasha. (2013). "The Second Class Citizens of the Google Cafeteria." Valley Wag, December 19, 2013. http: / / valleywag.gawker.com/the-second-class-citizens-of-the-google-cafeteria1486447319

Widrich, Leonhard. (2014). "The Origin of the 8 Hour Work Day and Why We Should Rethink It." The Blog, HuffPost Business, January 7, 2014. http:/ / www.huffingtonpost.com/leonhardwidrich/the-origin-of-the-8-hour-_b_4524488.html 